\title{
Tax Incentive Requests and Offers in a State Economic Development Program
}

\section{Todd M. Gabe and David S. Kraybill*}

\begin{abstract}
This paper analyzes expansion, relocation, and new business projects in Ohio between 1993 and 1995 to determine the characteristics that influence a project's probability of receiving a tax incentive from the state. Empirical results indicate that establishment size and age, high local wages, and high local air pollution levels decrease a project's probability of receiving tax assistance from the state government. The number of new jobs promised by the business establishment and the size of the county labor force increase a project's likelihood of receiving an incentive.
\end{abstract}

\section{BACKGROUND}

Tax incentives are widely used by states and communities to attract new and relocating businesses and to assist existing firms in undertaking expansions. There are many opinions on the usefulness and effects of incentive-based economic development strategies and on the importance firms place on the local tax climate (and incentives) as a location decision factor. Many studies written prior to 1985 report that taxes (and tax incentives) have little, or no, effect on establishment location decisions (Due 1961). Some more recent studies suggest that a positive relationship exists between low taxes and business location, especially at an intraregional level (Bartik 1985).

The interactions between communities demanding and firms supplying jobs can be viewed as a market in which rival locations offer incentive packages to attract new firms and jobs (Blair, Fichtenbaum, and Swaney 1984; Gabe 1996). In this market there is competition among communities, and communities and firms negotiating over incentives engage in strategic behavior (Wolkoff 1992; Oechssler 1994; Wohlgemuth and Kilkenny 1998).

Governments (and political officials) often seek to increase the number of jobs and stimulate growth in the local economy, which increases the tax base and may increase an official's probability of reelection. Firms act to maximize profits or size by finding the optimal location for new production, or by expanding capacity at an existing facility. Businesses may request incentives to offset more profitable opportunities to locate or expand in other locations. When the objectives of a government and firm are satisfied and sufficient benefits from added jobs are allocated between both parties, the firm undertakes a project with incentive assistance.

*Graduate Research Associate and Associate Professor, Department of Agricultural, Environmental and Development Economics, The Ohio State University, Columbus, OH.This paper benefited from the comments of two anonymous reviewers. This research was supported by a National Research Initiative grant from the United States Department of Agriculture. Salaries and research support provided by state and federal funds appropriated to the Ohio Agricultural Research and Development Center, The Ohio State University. All remaining errors are the responsibility of the authors. 
This paper develops a conceptual model of government and firm behavior and uses a logit model to predict an establishment's probability of participating in a state-level tax incentive program. The analysis addresses the question: under what circumstances are business expansions, relocations, or start-ups likely to involve tax incentives? The conceptual and empirical framework provides insight into the underlying behavior of governments and firms in choosing to offer incentives and undertake projects with or without incentive assistance.

Our intent in this paper is not to evaluate whether tax incentives have a significant impact on employment growth and locational decisions. Although other studies have analyzed the relationship between taxes and firm location and growth, our findings are not meant to support or reject any hypotheses related to the effectiveness of tax incentives. Rather, the paper focuses on the decision to offer tax incentives, and not on the actual employment effects of incentive programs.

To formalize the actions of governments and firms, we utilize the concepts of a state's willingness-to-pay for jobs and a firm's cost of job creation. Both measures are determined by characteristics of the business establishment and of the community where the project will occur. For instance, a state's willingnessto-pay for new jobs is likely based on levels of unemployment and market conditions in the community where the project is to occur, and characteristics of the new jobs and industry. Likewise, a firm's cost of job creation in a particular location is determined by its proximity to markets, the quality of the local labor force, and firm and sectoral technological factors.

This paper looks at the relationships between projects that receive incentive assistance from an Ohio economic development program and attributes that are internal and external to the firms. Our findings suggest that there is a negative relationship between a project's probability of receiving a tax incentive and establishment size and age. The probability of receiving tax assistance increases with project size as measured by promised new jobs. Average annual wages per worker in a county and a county's environmental nonattainment status are negatively related to the probability of a project receiving a tax incentive. The county labor force size and the probability of receiving tax assistance are positively related.

The plan of the paper is as follows. Section II develops a conceptual foundation that explains the behavior of states and firms in the incentive process. In section III, we discuss the empirical model and present the results of the logit estimation. The paper concludes with a discussion of the limitations of the model and empirical framework.

\section{CONCEPTUAL FOUNDATION}

The state government's objective is to maximize $\mathrm{S}=\omega(\mathrm{L} ; \Omega)-\mathrm{I}$, where $\omega_{\mathrm{L}}^{\prime}$ $(\mathrm{L} ; \Omega)>0, \omega_{\mathrm{L}}^{\prime \prime}(\mathrm{L} ; \Omega)<0$ and $\omega(0 ; \Omega) \leq 0$. The state's surplus (S) from any project is defined as the state's willingness-to-pay for jobs, represented as $\omega($.$) , in a$ particular firm in a given community, less any incentive (I) that may be offered by 
the government. ${ }^{1}$ The symbol $\Omega$ represents firm and community characteristics of a project and $(\mathrm{L})$ represents the number of jobs created by a project.

The state's underlying objective reveals implicit assumptions about government behavior related to the use of tax incentives. For example, state governments may have a willingness-to-pay for certain jobs added to a local area characterized by attributes that repel business activity. This willingness-to-pay for jobs is justified by the perceived benefits of increased industrialization and job creation in communities across the state. ${ }^{2}$ In Ohio, a criterion for receiving a Job Creation Tax Credit is that the "project is economically sound and will benefit the people of Ohio by increasing opportunities for employment." The state's willingness-to-pay for jobs represents an attempt to capture benefits that accrue to Ohio residents from increased employment opportunities.

The restrictions imposed on the origin and curvature of $w(L ; \Omega)$ imply that the average willingness-to-pay for jobs decreases as the size of the project increases. ${ }^{3}$ For some projects with $\mathrm{w}(\mathrm{L} ; \Omega)$ less than zero, the government is unwilling to pay for jobs added to a community. In these cases, costs from additional congestion or environmental damage or costs of extending local public goods and services outweigh any local benefits from additional jobs. ${ }^{4}$ These projects are not worthy of tax incentives from the point of view of the state.

Firm behavior is described in terms of the decision to allocate resources to a project that creates jobs in a specific location. The project may be a firm birth, expansion, or relocation. The assumption that underlies firm behavior is that the firm will undertake a project if its expected profits are greater than the return from alternative activities. The firm chooses the most profitable activity from (1) pursuing a project in a baseline community; (2) pursuing a project in any other community; or (3) undertaking some alternative investment.

In instances where the state would receive a surplus from a project, the government may offer tax incentives to the firm. The firm treats the incentive as a benefit in addition to the profit from undertaking a project. If the expected profits from a project in an alternative site are greater than in the baseline location, a tax incentive may influence a firm's allocation of resources from the alternative

${ }^{1}$ This general behavioral assumption is consistent with the incentive process outlined by Oechssler (1994) and Wohlgemuth and Kilkenny (1998). For example, a copy cat cost could be incorporated along with the incentive as a second component that decreases the state's surplus.

"Blair, Fichtenbaum, and Swaney (1984) motivate government behavior in the "market for jobs" on the bases of imperfect labor markets and economic stagnation in a region. In areas with some threshold level of unemployment, "(workers) should be willing to pay (for jobs) up to the costs - both monetary and psychic - of relocating for a comparable local job" (Blair, Fichtenbaum, and Swaney 1984, p.66). Benefits from local jobs may spread beyond affected workers to some property owners and, in the case in which new jobs are in basic sectors, to other local businesses and residents through the multiplier process. Blair, Fichtenbaum, and Swaney also suggest that the willingness-to-pay for jobs should vary across regions depending on their level of unemployment, public service and infrastructure capacity, and other factors.

${ }^{3}$ This is consistent with the decreasing marginal social benefit from additional jobs assumed by Blair, Fichtenbaum, and Swaney (1984).

'This notion expands Ihlanfeldt's (1995) first principle of offering effective and fair tax incentives. It states that "tax incentives should be accompanied by specific programs that seek to mitigate the unwanted side effects of economic growth." In our study, governments are assumed to have a negative willingness-to-pay for projects for which the unwanted side effects outweigh the external benefits. Thus, the underlying behavior predicted by the model is that tax incentives are not (or should not be) offered to firms undertaking projects with net negative external effects. 
community to the baseline community. ${ }^{5}$ The firm's decision rule when incentives are available is to pursue the project if $I \geq\left(P Y_{A}-W_{A} L_{A}-R_{A} K\right)-\left(P Y_{0}-W_{0} L_{0}-R_{0} K\right)$ $+\left(C_{A}-C_{0}\right)$, where the subscripts $(0)$ and $(A)$ indicate the baseline and alternative locations, respectively. We assume that output price $(\mathrm{P})$ and a firm's capital investment $(\mathrm{K})$ are the same in both locations. The output level $(\mathrm{Y})$, labor added by the firm (L), wage rate (W), rental rate of capital (R), and transactions costs of receiving an incentive $(C)$, however, vary across locations. The right-hand side of the firm's decision rule is defined as a firm's cost of job creation in the baseline community, $\mathrm{g}(\mathrm{L} ; \Omega)$, where $\mathrm{g}_{\mathrm{L}}^{\prime}(\mathrm{L} ; \Omega)>0$ and $\mathrm{g}_{\mathrm{L}}(\mathrm{L} ; \Omega)>0$.

Along with increasing the benefits of a project, the incentive may also add a set of tangible and intangible transaction costs to the firm. These include information, administrative, goodwill, and intervention costs. The information cost includes efforts on the firm's behalf to learn about the incentive program. A firm that is uninformed about an incentive program may have a prohibitively high cost of information and will never request an incentive. Firms also incur a tangible administrative cost when requesting tax incentives. This includes application costs and the expense of meeting with government officials to negotiate the size and terms of the incentive. ${ }^{6}$

The loss of goodwill is an intangible cost that may arise if the public's perception of a business changes based on its request for a tax incentive. Residents in some states and communities may view tax incentives as a form of corporate welfare and, in these areas, requesting an incentive may decrease a firm's level of goodwill. ' A second intangible cost of the incentive process is the possible increase in government awareness of, and intervention in, the firm's activities. An incentive request may require the firm to provide financial statements to the state government. ${ }^{8}$ Also, after the incentive is awarded, the government may request information from the firm to monitor the success of the program.

The underlying objectives of states and firms motivate their actions during the incentive process. Three general outcomes are consistent with the objectives of both agents. First, the model suggests that some firms will undertake projects in the baseline community without requesting an incentive. Second, firms may request incentives and be denied assistance from the government. When this occurs, firms will either undertake the most profitable alternative investment or

${ }^{5}$ Even if the baseline community provides the most profitable location for the project, firms may benefit by receiving an incentive. This causes the information problem analyzed by Oechssler (1994) and Wohlgemuth and Kilkenny (1998). Firms without an attractive alternative investment have an incentive to seek tax assistance by acting as if they have a relocation opportunity. A weakness of our model is that it is impossible to distinguish whether a firm receiving an incentive actually requires it to undertake a project, or whether the state merely entertained its bluff.

${ }^{6}$ The administrative costs are similar to lobbying costs defined by Oechssler (1994) as spending in a media campaign, taking government officials to dinner, etc.

${ }^{7} \mathrm{~A}$ firm's reputation can be hurt even in cases when they request and are denied a tax incentive. If a firm undertakes a project after being denied an incentive, the state and community learn that the incentive request was a bluff. This may adversely affect future relations between government agencies and the firm.

'In Oechssler's (1994) model, a policy instrument at the government's disposal is the decision whether to audit a firm that requests an incentive. An equilibrium in Oechssler's firm-versus-city subsidy game is to respond to a firm's subsidy lobby with a random strategy of offering an incentive and auditing the firm. 
complete the project in its original location. A third outcome is that some firms will request incentives and receive tax assistance.

\section{EMPIRICAL SPECIFICATION}

Our underlying models of government and firm behavior suggest that firm and community characteristics determine whether a project receives a tax incentive. The extent to which any project meets the state's willingness-to-pay and the firm's cost of job creation criteria is unobservable. We observe only whether a project receives a tax incentive or whether projects occur without incentive assistance.

The variable $Z_{i}$ is an unobserved variable that indexes how closely a project meets the criteria for receiving a tax incentive. As suggested by the model, $Z_{i}$ is related to a set $\left(X=X_{i}, \ldots, X_{n}\right)$ of firm and community characteristics. The variable $Z_{i}^{*}$ is a critical value of $Z_{i}$ that determines whether a project both meets criteria and receives an incentive. The variable $\Psi_{\mathrm{i}}$ is an observed variable that equals one if a project receives an incentive and zero if the project occurs without tax assistance.

$$
\begin{aligned}
& \Psi_{i}=1, \text { if } Z_{i} \geq Z_{i}^{*} \\
& 0 \text {, otherwise }
\end{aligned}
$$

A logit model estimates the probability that a project receives incentive assistance given the characteristics of the firm and community.

$$
\pi_{\mathrm{i}}=\operatorname{Prob}\left(\Psi_{\mathrm{i}}=1\right)=\left\{\exp \left(\beta \mathrm{X}_{\mathrm{i}}\right) /\left(1+\exp \left(\beta \mathrm{X}_{\mathrm{i}}\right)\right)\right\}
$$

where $\pi_{\mathrm{i}}=$ project's probability of receiving a tax incentive

$\Psi_{\mathrm{i}}=$ indicator variable that equals one if project receives incentive, zero otherwise

$X_{i}=a$ vector of firm and community characteristics

\section{Program Description and Data}

A logit model is used to analyze the relationship between a project's probability of receiving an incentive from Ohio's Job Creation Tax Credit program and selected firm and community characteristics. ${ }^{9}$ The program provides a corporate tax credit that is equal to a percentage of the income taxes withheld from workers holding jobs created by the project. ${ }^{10}$ Larger tax credits (per promised job) are typically offered to firms that promise a large number of jobs, that promise high wages, that purchase intermediate goods from Ohio firms, or that locate in "distressed" areas (Wasylenko 1996).

The data set consists of information regarding business establishments that announced major projects (as reported in Site Selection magazine) in Ohio between 1993 and 1995. It is comprised of businesses announcing projects that, in

\footnotetext{
'The Ohio Job Creation Tax Credit Program is explained by Wasylenko (1996) and Gabe (1996).

${ }^{10}$ Tax credit amounts are based on the number of jobs the establishment plans to create in the project and the credits are presumably applied to the establishment's corporate taxes regardless of whether the jobs are actually created.
} 
principle, would be candidates for receiving tax incentives from the state. The establishment-level data was collected in a questionnaire sent to approximately 1,000 businesses that planned expansions between 1993 and 1995. From this survey, there were 494 usable responses. Site Selection lists projects that promise an investment of $\$ 1$ million or more, a square footage increase greater than 20,000 , or 50 or more new jobs, so the projects included in this paper are all substantial in size. The projects are generally in the manufacturing or distribution sectors, though some office, research and development, retail, and hotel establishments are included.

Of the 494 projects in the data set, 156 received a Job Creation Tax Credit in 1993, 1994, or $1995 .{ }^{11}$ Tax incentives are generally restricted to manufacturing, distribution, research and development, and other high-technology firms. Some conditions for receiving a tax credit are that the project creates new jobs, the project is "economically sound" and benefits Ohio residents, and the recipient firm must declare that the incentive is a factor in the firm's decision to undertake the project. These conditions are consistent with the underlying model of state and firm behavior. If the project benefits Ohio residents in communities with economic distress, it is likely that the state government has a willingness-to-pay for the added jobs.

\section{Explanatory Variables}

The variables expected to predict whether a project receives an incentive are the firm and community characteristics commonly used to explain firm growth and locational decisions. Other variables are chosen that may affect a state's willingness-to-pay for jobs or a firm's cost of job creation. The SIZE and AGE of a business establishment are likely to be correlated with its probability of receiving tax assistance. Young firms typically grow faster than older firms, and in most recent studies firm growth is negatively correlated with size (Evans 1987; Variyam and Kraybill 1992). Ohio's tax credit program is also believed to favor new and expanding businesses (Wasylenko 1996). The higher levels of growth expected in young, small firms and the program's apparent bias toward small businesses suggest that the establishment age and size variables are negatively correlated with the probability of receiving an incentive.

The PROJECT size is the number of jobs the establishment promises to create in the community. The model suggests that total state benefits increase while the marginal benefit decreases with each added job. Furthermore, the firm's cost of job creation increases with each promised job. Since the project size increases the state's benefit from new jobs and the firm's cost of job creation, this variable is expected to be positively correlated with the probability of receiving tax assistance.

The establishment's RATE of employment change between 1990 and 1993 is expected to be negatively related to the probability of receiving an incentive.

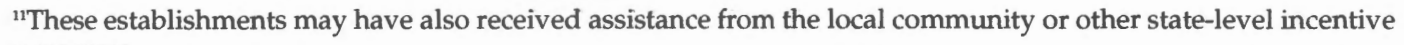
programs. 
The rate of prior growth is the difference in logarithms of establishment employment between 1990 and 1993, divided by three. Growth between 1990 and 1993 without incentive assistance suggests that the business' current baseline location is (or at least was recently) profitable. On the other hand, if establishment employment declined between 1990 and 1993, it is more likely that it would require an incentive to create jobs in the following period.

The establishment's INDUSTRY (by two-digit SIC) and TYPE (headquarters, branch plant, or single location) are included as control variables in the logit analysis. The industry dummy variables are expected to capture the impacts of wages and job characteristics that vary across sectors. Establishment type is expected to account for the differences in employment change and location decisions between single-unit enterprises and businesses that are part of a multi-establishment firm. Branch plant establishments may be more "footloose" and therefore more likely to be offered incentives than single establishments that are presumably tied to a particular location.

Several community factors are expected to influence whether a project receives a tax incentive. County economic characteristics and market conditions in the project's location should affect the firm's cost of job creation. Also, given that the state's incentive program may have a bias toward financing projects in "distressed" areas, adverse local conditions should influence the government's willingness-to-pay for jobs in areas across the state.

County-level EDUCATIONAL attainment is likely to be negatively correlated with the probability of receiving a tax incentive. A highly educated local work force should lower a firm's cost of job creation and allow it to undertake a project without incentive assistance. Likewise, a poorly educated work force is likely to exist in distressed communities, which suggests the state's willingnessto-pay for jobs increases the lower the local level of educational attainment.

The county's DISTANCE from a metropolitan area and the miles of interstate HIGHWAY in the county are indicators of the firm's access to markets outside the community. Firms should have a lower cost of job creation in (or near) major markets or locations accessible to national markets via interstate highways. These firms are less likely, therefore, to request a tax incentive.

County per capita money WAGES and the county UNEMPLOYMENT rate are indicators of an area's level of economic well being. As the county unemployment rate increases, the state is assumed to be more willing to pay for new jobs added in the county. This increases a project's probability of receiving tax assistance in areas with high unemployment. On the other hand, a high unemployment rate may decrease a firm's cost of job creation in the county if high levels of unemployment decrease the reservation wage of local residents. This lowers a project's chance of receiving an incentive. Thus, we have no prior expectation of the direction of the relationship between unemployment and the probability of receiving an incentive. The relationship between county per capita wages and a project's probability of receiving a tax incentive is also ambiguous. 
The size of the county LABOR force is expected to positively impact the probability of a project receiving tax assistance. ${ }^{12}$ The labor force size measures local product and labor markets. As the labor force increases, the firm should have a larger pool of potential workers, which may decrease its cost of job creation. On the other hand, the state may have a greater willingness-to-pay for jobs added to more populated areas if other variables such as unemployment are constant. These areas may have a greater political significance than more sparsely populated counties. Since a large county work force is correlated with greater representation in the state legislature (and the possibility of the project potentially benefiting more people), projects in these areas may have a greater probability of receiving tax assistance.

The environmental NONATTAINMENT status in each county is a dummy variable that indicates whether local pollution levels exceed environmental standards for sulfur dioxide, nitrogen dioxide, carbon monoxide, ozone, lead, and particulate matter less than ten milacrons in diameter..$^{13}$ Plants that emit these pollutants into the air may be forced to adopt costly technologies to reduce discharge levels. Thus, polluting firms may have a high cost of job creation in areas that do not meet attainment criteria. Clean firms may require incentives to locate in heavily polluted areas because of negative externalities. If pollution is a disamenity to management in nonpolluting firms, incentives from the state may increase the desirability of a location that is close to nonattainment status vis a vis other sites. From the state's perspective, the willingness-to-pay for jobs may be greater in nonattainment counties because of the difficulty of attracting jobs without incentives. Considering the relative strength of these factors, the probability of receiving an incentive is expected to increase in counties that do not meet attainment status.

\section{Estimation Results}

The following model is used to estimate the relationship between a project's probability of receiving a tax incentive and a vector of firm and community characteristics related to the project.

$$
\pi_{\mathrm{i}}=\left\{\exp \left(\beta \mathrm{X}_{\mathrm{i}}\right) /\left(1+\exp \left(\beta \mathrm{X}_{\mathrm{i}}\right)\right)\right\}
$$

where $\pi_{\mathrm{i}}=$ project's probability of receiving a tax incentive

$$
\begin{aligned}
\beta X_{i}= & \beta_{0}+\beta_{1} \text { AGE }+\beta_{2} \text { PROJECT }+\beta_{3} \text { SIZE }+\beta_{4} \text { RATE }+ \\
& \beta_{5} \text { EDUCATIONAL }+\beta_{6} \text { WAGES }+\beta_{7} \text { UNEMPLOYMENT }+ \\
& \beta_{8} \text { LABOR }+\beta_{9} \text { DISTANCE }+\beta_{10} \text { HIGHWAY }+
\end{aligned}
$$

\footnotetext{
${ }^{12}$ The state and firm models suggest that the expected relationship between labor force size and the probability of receiving assistance is ambiguous. It is likely that a large labor force decreases a firm's cost of job creation. The relationship between the state's willingness-to-pay for jobs and the county labor force, on purely economic grounds, is uncertain. The county labor force, which is closely related to the area's population size, is probably more important politically at the state level. We expect that the political factors that increase the probability of receiving an incentive outweigh the economic factors that decrease a firm's cost of job creation.

${ }^{13} \mathrm{McC}$ Connell and Schwab (1990) found no correlation between industrial location decisions and attainment or nonattainment status. They did find (taking into account the degree of environmental distress) that firms are less likely to locate in areas with heavy ozone pollution.
} 


\section{$\beta_{11}$ NONATTAINMENT $+\beta_{12,13}$ TYPE $+\beta_{14,15, \ldots, 30,31}$ INDUSTRY}

Two sets of dummy variables control for the relationships between establishment type and industry and the probability of receiving tax assistance. Establishment type dummy variables indicate whether the project is undertaken by a branch plant of a multi-establishment firm or the headquarters of a multiestablishment firm. The omitted group includes single-unit establishments and businesses that are not classified. ${ }^{14}$ The industry variables control for sectorspecific effects. The service (SIC 60-67, 70-97) sector is the omitted category in the set of industry dummy variables.

\section{TABLE 1}

Descriptive Statistics of 494 Projects by Ohio Business Establishments in 1993, 1994, and 1995

\begin{tabular}{lrr}
\hline Variable & Mean & $\begin{array}{c}\text { Standard } \\
\text { Deviation }\end{array}$ \\
\hline Receipt of Incentive & 0.32 & NA \\
Establishment Age & 21.32 & 26.15 \\
Project Size & 76.70 & 125.99 \\
1993 Employment Size & 281.89 & 958.21 \\
1990-1993 Rate of Employment Change & 0.15 & 0.37 \\
County Educational Attainment & 12.33 & 0.40 \\
Average Annual Wages (1,000) & 23.06 & 7.86 \\
County Unemployment & 6.85 & 1.45 \\
County Labor Force & 153,630 & 188,290 \\
Distance from Metropolitan Area & 15.44 & 15.52 \\
Interstate Highway Mileage & 34.46 & 36.74 \\
Environmental Nonattainment & 0.53 & NA \\
Branch Plant & 0.44 & NA \\
Headquarters & 0.12 & NA \\
Single-Unit Establishment & 0.41 & NA \\
Other Establishment & 0.04 & NA
\end{tabular}

\begin{tabular}{lc}
\hline Industry & Percentage \\
\hline Services (SIC 70-97) & 2.83 \\
FIRE (SIC 60-67) & 1.42 \\
Wholesale and Retail Trade (SIC 50-59) & 9.11 \\
Transportation and Public Utilities (SIC 40-49) & 1.42 \\
Food and Kindred Products (SIC 20) & 4.45 \\
Textiles (SIC 22-23) & 0.61 \\
Lumber, Wood, Furniture and Fixtures (SIC 24-25) & 2.63 \\
Paper and Allied Products (SIC 26) & 5.26 \\
Printing and Publishing (SIC 27) & 2.83 \\
Chemicals and Petroleum Products (SIC 28-29) & 4.25 \\
Rubber and Plastic Products (SIC 30) & 11.54 \\
Leather Products (SIC 31) & 0.41 \\
Stone, Clay and Glass Products (SIC 32) & 4.45 \\
Primary Metal Industries (SIC 33) & 6.28 \\
Fabricated Metal Products (SIC 34) & 10.32 \\
Industrial Machinery and Equipment (SIC 35) & 15.79 \\
Electronic Equipment (SIC 36) & 5.87 \\
Transportation Equipment (SIC 37) & 8.70 \\
Instruments and Related Products (SIC 38) & 1.01 \\
Miscellaneous Manufacturing (SIC 39) & 0.81 \\
& \\
& "The survey instrument asked the respondent to choose the firm's type from the following: (a) branch plant \\
of a multi-establishment firm; (b) headquarters of a multi-establishment firm; (c) single-unit establishment; or (d) \\
other. The omitted group contains single-unit establishments and the 4 percent of firms that are classified' in the \\
"other" category.
\end{tabular}


Descriptive statistics of the 494 projects announced in Ohio between 1993 and 1995 are shown in table 1 . They indicate that 32 percent of the projects (156 in total) received tax incentives. The average age of an establishment undertaking a project is 21 years old, and the average size in 1993 (before the project) is 282 workers. The average project promises to add 77 new jobs. Businesses in various industries undertook projects. The industrial machinery and equipment (SIC 35), rubber and plastic products (SIC 30), and fabricated metal products (SIC 34) sectors, however, accounted for over 30 percent of the projects included in this paper. Table 2 presents the results of the logit analysis. The firm and community characteristics in our model are significantly correlated with a project's probability of receiving a tax incentive. The likelihood ratio for the set of explanatory variables is significant at the 99th percentile (chi-square value of 55.42 with 31 degrees of freedom). The model correctly predicts the outcome (whether a project receives an incentive or whether it occurs in the state without assistance) of 72 percent of the projects. The average project has a 29 percent chance (calculated at mean values) of receiving a tax incentive.

TABLE 2

Logit Results of 494 Projects by Ohio Business Establishments in 1993, 1994, and 1995

\begin{tabular}{|c|c|c|c|c|}
\hline Variable & Coefficient & $\begin{array}{l}\text { Asymptotic } \\
\text { Standard } \\
\text { Error }\end{array}$ & $\begin{array}{c}\text { Asymptotic } \\
\text { T-ratio }\end{array}$ & $\underset{\text { Effect }^{+}}{\text {Marginal }}$ \\
\hline Constant & -38.405 & 274.010 & -0.140 & -7.898 \\
\hline Establishment Age & -0.011 & 0.005 & $-2.293^{*}$ & $-0.023(10)$ \\
\hline Project Size & 0.004 & 0.001 & $3.494^{* *}$ & $0.082(100)$ \\
\hline 1993 Employment Size & -0.001 & $2.84 \mathrm{E}-04$ & $-1.764^{*}$ & $-0.010(100)$ \\
\hline 1990-1993 Rate of Employment Change & -0.659 & 0.318 & $-2.072^{* *}$ & -0.135 \\
\hline County Educational Attainment & 0.096 & 0.469 & 0.204 & 0.020 \\
\hline Average Annual Wages & -0.035 & 0.023 & -1.540 & $-0.007(1,000)$ \\
\hline County Unemployment & 0.036 & 0.098 & 0.371 & 0.007 \\
\hline County Labor Force & $3.12 \mathrm{E}-06$ & $1.04 \mathrm{E}-06$ & $2.993^{* *}$ & $0.001(1,000)$ \\
\hline Distance from Metropolitan Area & 0.005 & 0.010 & 0.473 & $0.010(10)$ \\
\hline Interstate Highway Mileage & 0.019 & 0.138 & 0.135 & $0.038(10)$ \\
\hline Environmental Nonattainment & -0.594 & 0.309 & $-1.924^{*}$ & -0.122 \\
\hline Branch Plant & 0.221 & 0.231 & 0.954 & 0.045 \\
\hline Headquarters & 0.079 & 0.358 & 0.220 & 0.016 \\
\hline Wholesale and Retail Trade & -0.842 & 0.613 & -1.372 & -0.173 \\
\hline Transportation and Public Utilities & -0.282 & 0.942 & -0.299 & -0.058 \\
\hline Food and Kindred Products & -0.269 & 0.677 & -0.397 & -0.055 \\
\hline Textiles & -4.801 & 5.209 & -0.922 & -0.987 \\
\hline Lumber, Wood, Furniture and Fixtures & -1.426 & 1.022 & -1.395 & -0.293 \\
\hline Paper and Allied Products & 0.697 & 0.640 & 1.088 & 0.143 \\
\hline Printing and Publishing & -0.004 & 0.775 & -0.006 & -0.001 \\
\hline Chemicals and Petroleum Products & -0.002 & 0.681 & -0.003 & $-3.73 \mathrm{E}-04$ \\
\hline Rubber and Plastic Products & 0.021 & 0.565 & 0.038 & 0.004 \\
\hline Leather Products & 0.352 & 1.799 & 0.196 & 0.072 \\
\hline Stone, Clay and Glass Products & 0.217 & 0.662 & 0.327 & 0.045 \\
\hline Primary Metal Industries & 0.292 & 0.608 & 0.481 & 0.060 \\
\hline Fabricated Metal Products & -0.526 & 0.583 & -0.902 & -0.108 \\
\hline Industrial Machinery and Equipment & -0.397 & 0.544 & -0.730 & -0.082 \\
\hline Electronic Equipment & 0.188 & 0.622 & 0.302 & 0.039 \\
\hline Transportation Equipment & -0.306 & 0.603 & -0.508 & -0.063 \\
\hline nd Related Products & -0.081 & 1.098 & -0.074 & -0.017 \\
\hline Miscellaneous Manufacturing & 0.811 & 1.131 & 0.717 & 0.167 \\
\hline
\end{tabular}

Likelihood Ratio $=55.42^{* *}$ with 31 degrees of freedom aCalculated at mean values

*Significant at $10 \%$ level

**Significant at 5\% level 
Establishment age and size are negatively correlated with a project's probability of receiving a tax incentive. These results are consistent with the hypothesis that Ohio's tax incentive program favors small and young establishments. At the margin, businesses that are 10 years older than the average establishment are 2 percentage points less likely to receive tax assistance ${ }^{15}$ Projects undertaken in establishments that have 100 more workers than the average are 1 percentage point less likely to receive a tax incentive. Thus, an establishment that began operations in 1955 and had 600 employees at the beginning of 1993 has a 21 percent chance of receiving tax assistance to undertake an expansion project, compared to the average establishment's 29 percent chance. ${ }^{16}$

The project size, in terms of promised new jobs, is positively related to the probability of receiving tax assistance. This is consistent with assumptions in the model that the state has a higher willingness-to-pay for large projects and that a firm's cost of job creation increases with the number of promised jobs. The estimates suggest that, at the margin, a project is 8 percentage points more likely to receive tax assistance for every 100 promised jobs above the mean ( 77 jobs). Thus, the average project promising 400 new jobs has an approximately 55 percent chance of receiving a tax incentive from the state.

An establishment's positive rate of employment change between 1990 and 1993 significantly decreases a project's probability of receiving a tax incentive. This confirms our expectation that the incentive program favors establishments that have a net decrease in employment size (a sign of establishment distress) in the years before requesting an incentive.

Several community characteristics are correlated with the probability of a project receiving tax assistance. A county's nonattainment environmental status decreases a project's probability of receiving a tax incentive, and high local wages tend to decrease a project's chance of receiving tax assistance. ${ }^{17}$ The logit estimates suggest that for every $\$ 1,000$ (above the average of $\$ 23,060$ ) in average annual county wages per worker, a project is 0.7 percentage points less likely to receive an incentive. This is consistent with the incentive program's objective of providing assistance to establishments that undertake projects in distressed areas. The relationship between environmental quality and the dependent variable suggests that projects in nonattainment counties are 12 percentage points less likely to receive tax assistance. This may indicate that, contrary to our expectations, the state has a lower willingness-to-pay for jobs added in nonattainment counties (or that a firm's cost of job creation is lower in nonattainment counties).

The logit estimates suggest that a positive correlation exists between the size of the county labor force and a project's probability of receiving tax assistance. For every 100,000 workers in a county (above the mean of 153,630 ), a project's probability of receiving an incentive rises by 10 percentage points. This finding

${ }^{15} \mathrm{~A}$ reason for this finding may be that a large number of start-up establishments receive tax incentives.

${ }^{16}$ The economic significance of these results is uncertain. An establishment must be 50 years older, or 1,000 workers larger, than the average establishment to be 10 percentage points less likely to receive incentive assistance. Fifty years older than the average establishment represents two standard deviations from the mean. One thousand additional workers in 1993 is almost one standard deviation from mean values. 
may confirm the notion that projects in areas with greater political representation have a higher probability of receiving tax assistance from the state.

The firm type and industry dummy variables are insignificant in explaining a project's probability of receiving an incentive. This suggests that incentives are not offered with more frequency to specific firm types or industries.

\section{CONCLUSIONS}

The empirical results suggest that the incentive projects undertaken by Ohio establishments are largely consistent with our state and firm optimization models. Establishment size and age (although not establishment type or industry) and project size are related significantly to a project's probability of receiving a tax incentive. The findings, however, provide mixed support for the notion that incentives are used to assist businesses that locate or expand in distressed areas. Although a project's probability of receiving an incentive increases in areas with lower per capita wages, there is no evidence that incentives favor projects that occur in areas with limited market access, as measured by a county's distance from a major city and interstate miles in the county.

The theoretical foundation and empirical model, however, may benefit from some refinements that more accurately describe the behavior of states and business establishments. First, the empirical model is unable to separate the effects of a state's willingness-to-pay for jobs from the effects of a firm's cost of job creation on a project's probability of receiving a tax incentive..$^{18}$ The community characteristics that affect a firm's cost of job creation in a county also influence the state's willingness-to-pay for jobs in that area. In some cases, a community characteristic (such as county educational attainment) increases both a firm's cost of job creation and the state's willingness-to-pay for jobs. Other factors, however, increase a firm's cost of job creation and decrease the state's willingness-to-pay for jobs. This leads to ambiguous relationships between community conditions and the probability of receiving tax assistance. For instance, other things being equal, high money wages in a county should increase a firm's cost of job creation and lower the state's willingness-to-pay for jobs. Our models of government and firm behavior, therefore, suggest opposing signs for the relationship between a project's probability of receiving an incentive and local money wages. Likewise, the conceptual framework does not suggest a clear-cut relationship between county labor force size and the probability of receiving an incentive. In these cases where the state and firm models suggest that there are opposing forces, the result is an empirical question.

A second suggestion for future research is to incorporate into the analysis imperfect information that may arise in the incentive process. The model does not

${ }^{17}$ The receipt of tax incentives and county wages are related at a level slightly lower than the $10 \%$ significance level.

${ }^{18}$ In other words, the empirical model is unable to separate supply and demand factors that influence whether a project receives incentive assistance. Modeling the incentive process as a market for jobs (with incentive prices and job quantities) would enable us to isolate the effects of firm and community characteristics on incentive demand and supply. 
address the problem of firms that request incentives but do not actually need them to undertake a project. If the state has perfect information, incentives are given only to projects with a positive cost of job creation. On the other hand, suppose that all firms are bluffing about their need for an incentive. In this extreme case, the empirical results may say more about a firm's ability to bluff than about its cost of job creation.

A third suggestion for future research is to extend the analysis to include establishments that request and are denied incentives. Our analysis is limited to projects that occur with tax incentives and projects that businesses undertake without incentive assistance because we do not have information on firms that request incentives but are denied them by the state government. Some of the businesses that undertook projects without assistance likely requested incentives from the state and were turned down. Incorporating information on the decisions made by firms that are denied incentives would enable us to analyze a second component of the incentive process. The process could be expanded to capture the firm's decision to apply for an incentive, the state's decision to grant an incentive, and the firm's choice to undertake the project (with or without tax assistance). The model currently explains a firm's decision to apply for and accept, and a government's decision to offer, tax incentives.

These suggestions for future research will extend our analysis of state and firm behavior in the incentive-based job market. In this study we have laid out a conceptual foundation that suggests that incentive projects must meet a state's willingness-to-pay criterion and a firm's cost of job creation criterion. We find that tax incentive outcomes are largely consistent with our model of firm behavior and somewhat consistent with economic development objectives in the state of Ohio. The empirical results suggest that the tax incentive program favors young and small establishments, that incentives are more frequently given to businesses that promise a large number of jobs, and that incentives are used to stimulate growth in declining establishments. The program also favors low wage counties, environmentally clean areas, and counties with large labor forces.

\section{REFERENCES}

Bartik, T.J. "Business Location Decisions in the United States: Estimates of the Effects of Unionization, Taxes, and Other Characteristics of States." Journal of Business and Economic Statistics 3 (1985), 14-22.

Blair, J.P., R.H. Fichtenbaum, and J.A. Swaney. "The Market for Jobs: Locational Decisions and the Competition for Economic Development." Urban Affairs Quarterly 20 (1984), 64-77.

Due, J. F. "Studies of State-Local Tax Influences on Location of Industry." National Tax Journal 14 (1961), 163-173.

Evans, D.S. "Tests of Alternative Theories of Firm Growth." Journal of Political Economy 95(1987), 657-674.

Gabe, T.M. "Are Tax Incentives for Economic Development Rational?" Journal of Regional Analysis and Policy 26 (1996), 87-100. 
Ihlanfeldt, K.R. "Ten Principles for State Tax Incentives." Economic Development Quarterly 9 (1995), 339-355.

McConnell, V.D., and R.M. Schwab. "The Impact of Environmental Regulation on Industry Location Decisions: The Motor Vehicle Industry." Land Economics 66 (1990), 67-81.

Oechssler, J. "The City vs. Firm Subsidy Game." Regional Science and Urban Economics 24(1994), 391-407.

Variyam, J.N., and D.S. Kraybill. “Empirical Evidence on Determinants of Firm Growth." Economics Letters 38 (1992), 31-36.

Wasylenko, M. "The Role of Fiscal Incentives in Economic Development: How Ohio Stands Relative to its Competitor States." In R. Bahl (ed.) Taxation and Economic Development: A Blueprint for Tax Reform in Ohio. Columbus, Ohio: Battelle Press, 1996.

Wohlgemuth, D., and M. Kilkenny. "Firm Relocation Threats and Copy Cat Costs." International Regional Science Review 21 (1998), 139-162.

Wolkoff, M.J. "Is Economic Development Decision Making Rational?" Urban Affairs Quarterly 27 (1992), 340-355. 